Bolm Inst. oceanogr., S Paulo, 26:303-338, 1977

\title{
MÉTODOS DE CULTURA DE ALGAS DO PLÂNCTON MARINHO: ESTUDOS REALIZADOS NAS REgIÕES DE CANANÉIA E DE UBATUBA, SP,
}

\author{
ARMANDO A. H. VIEIRA*
}

Instituto Oceanogräfico da Universidade de São Paulo

\section{SYNOPSIS}

The study of algae culture collected in Brazilian waters was proposed due to the lack of literature on the subject: an attempt was made to develop a methodology to obtain algae culture and its purification.

Several species were isolated from samples collected a Ubatuba and Cananéia (São Paulo) (Lat. 23030's - Long. $45^{\circ} 06^{\prime} \mathrm{W}$ and Lat. $25^{\circ} 01^{\prime} \mathrm{S}$ - Long. $\left.47^{\circ} 54^{\prime} \mathrm{W}\right)$ by means of phytoplankton net and Van Dorn bottle.

The following isolation techniques were employed after washing and concentration: glass capillary, inoculation of mixed cultures on Petri dishes with solid medium and positive phototropism.

The isolated algae were kept in five different mediuns. Washing techniques were tested (centrifugation, "filter tubes" and re-isolation), antibiotics and ultra violet radiation to obtain unialgal bacteria-free cultures were employed to obtain pure cultures. Five differents antibiotics, mixed in differents concentrations, were employed during several periods of expositions. The re-isolation proved to be the best method to obtain the purification of the cultures.

\section{NTRODUÇÃO}

A importância da obtenção de culturas unialgais planctônicas está na grande variedade com que as mesmas podem e devem ser utilizadas com finalidades as mais diversas: na genética, citologia, morfologia, taxonomia e fi-

* Contratado pelo FINEP para o "Projeto Integrado para Uso e Exploração Racional do Ambiente Marinho".

PUBL. NO 409 DO INST. OCEAN. DA USP. 
siologia vegetal; nas pesquisas de carāter experimental, como fonte de alimento para animais marinhos em várias fases do desenvolvimento (com finalidades científicas ou econômicas) e ultimamente também como fonte de proteínas para o consumo humano, produzidas em culturas em grande escala, (são encontradas no mercado na forma de pílulas, como fonte proteíca, produzidas pela companhia japonesa Chlore1la Industry Co). Um outro emprego de culturas unialgais planctônicas é no campo da ecologia em estudos ecofisiológicos do fitoplâncton marinho e da água doce, objetivando-se um acoplamento entre os trabalhos de campo e de laboratório. As pesquisas nesse sentido encontram-se atualmente em pleno desenvolvimento na oceanografia e limnologia modernas, abrindo novas perspectivas em trabalhos de ecologia aquática: além das pesquisas de natureza básica, podem ser citadas algumas aplicações na recuperação de grandes reservatórios eutroficados para abastecimento de água potável ou para recreação, onde grandes florescimentos de algas como gênero Microcystis e Anabaena comprometem tais utilizações, devido ao gosto e ao cheiro que tais algas dão às águas.

Neste trabalho enfatizamos a obtenção de culturas do fitoplâncton*marinho principalmente para estudos ecofisiológicos. Há possibilidades de, sob certas condições, se realizar experimentos no mar com populações naturais. Em regiões tropicais, principalmente, há um sério problema: trabalhando-sé com baixas concentrações de algas unicelulares os experimentos tornam-se falhos, devido à imprecisão de muitas técnicas ainda em uso. Assim, para responder às questões levantadas pelos estudos realizados "in situ", alguns dos melhores resultados têm sido obtidos através dos conhecimentos indiretos adquiridos em trabalhos experimentais com culturas de algas, empregando-se parâmetros semelhantes aos que ocorrem na natureza. A obtenção em laboratōrio de condições semelhantes às que ocorrem na natureza, tais como: luz (intensidade luminosa e composição espectral), temperatura, composição de nutrientes e os fenômenos de turbulência, torna-se na prática, difícil. No entanto, é possível imitar, dentro de certos 1 imites, alguns parâmetros isolados ou algumas combinações de parâmetro. Assim, as investigações relativas à produtividade primária nos meios aquáticos naturais podem, muitas vezes, ser suplementadas pelos conhecimentos das características fotossintéticas de espécies do fitoplâncton em culturas unialgais axênicas sob condições controladas em laboratório. 


\section{METODOLOGI A}

A metodologia para a obtenção e purificação de culturas de algas fitoplanctônicas pode ser consultada em trabalhos de vários autores estrangeiros. No entanto, o sucesso na aplicação da metodologia depende, entre outros fatores, de certas informações prévias da experiência aplicada à rotina metodológica. Por esse motivo e levando-se em conta que nada foi publicado no Brasil sobre o assunto, os métodos de obtenção e purificação de culturas empregados neste trabalho são adaptados daqueles descritos por vários autores. (Pringsheim, 1946; Chu, 1947; Fish, 1950; Gerloff et al., 1950; Spencer, 1952; Zehnder \& Hughes, 1958; Guillard \& Ryther, 1962; Droop, 1967, 1969; Paredes, 1967-1968; Guillard, 1973) com o objetivo de se conseguir uma metodologia que possa ser empregada rotineiramente em qualquer laboratório.

\section{MEIOS DE CULTURA PARA FITOPLÂNCTON}

Desde que Mique1 em 1890 (cit. in: Pringsheim, 1946) empregou sua solução nutriente para o cultivo de algas, inúmeros meios de cultura têm sido desenvolvidos:

a) meios naturais (enriquecimento da água do mar), ou

b) meios sintéticos, muitos deles variando entre sí apenas com algumas modificações qualitativas ou quantitativas.

Neste trabalho foram empregados os seguintes meios:

- Meios "f" e "f $f_{1}$ (Guillard \& Ryther, 1962)

- Erd-Schreiber (Gross, 1937)

- $\mathrm{ASP}_{2}$ (Provasoli, McLaughlin \& Droop, 1957)

Além dos meios líquidos, como os citados acima, são também muito empregados para culturas de certas espécies, meios sólidos, basicamente compostos de água distilada/água do mar, agar e sais nutrientes. 0 meio sólido empregado aqui foi o MSA (Meio Sólido para Algas, baseado no descrito por Chu, 1947). 
A escolha dos meios citados foi feita, levando-se em consideração os seguintes fatos:

1 - Os meios escolhidos são intensamente utilizados por diversos autores em trabalhos de culturas e fisiologia do fitoplâncton marinho, permitindo desse modo melhores comparações de resultados.

2 - Os meios Guillard "f" e " $f_{1}$ " mostraram-se favoráveis para o cultivo de todas as espécies empregadas neste trabalho. Além disso, o enriquecimento relativamente elevado com nutrientes, empregados nestes meios, minimiza as possíveis variações da composição química por mineralizações quando da estocagem da āgua do mar. Essé fato ē de extrema importância emexperiências de fisiologia, quando uma mesma amostra de āgua é utilizada em vārios experimentos, porém, em tempos diferentes. É também um meio favorável para a obtenção de culturas axênicas.

3 - 0 meio Erd-Schreiber foi empregado apenas para testar sua potencialidade para a manutenção de estoques de culturas e possivelmente cultivo em escalas maiores do que as empregadas neste trabalho, principalmente pelo fato de ser, entre os meios citados, o mais econômico.

4 - 0 meio $\mathrm{ASP}_{2}$ por ser relativamente pobre em matéria orgânica, é propício para a obtenção de culturas axênicas. Uma outra vantagem deste meio é a de ser sintético, o que possibilita seu emprego em trabalhos onde a composição química do meio deva ser conhecida, como em ensaios biológicos com nutrientes .

5 - 0 meio sólido para algas foi empregado com o principal objetivo de manutenção de estoques de cultura. Foi escolhido o meio Chu (1947, modif.) devido à facilidade de sua confecção.

A composição dos diversos meios, com algumas alterações das fórmulas originais, é apresentada na Tabela I. A āgua do mar empregada nos meios sempre foi originada dos locais de onde foram isoladas as espécies. A salinidade das águas de Cananéia e de Ubatuba, onde foram feitas as coletas de algas para este trabalho, foi de $21 \%$ e $32 \%$ respectivamente, determinada segundo o método de Harvey (1955). 
TABELA 1 - Componentes dos diversos meios usados neste trabalho e suas concentrações, segundo a bibliografia

\begin{tabular}{|c|c|c|c|c|c|c|c|}
\hline Componentes & "f" e "f & $E_{1} "$ & $\underset{\text { Erd- }}{\text { Echreiber }}$ & $\mathrm{ASP}_{2}$ & & MSA & \\
\hline $\mathrm{NaNO}_{3}$ & 150 & $\mathrm{mg}$ & $100 \mathrm{mg}$ & 50 & $\mathrm{mg}$ & 100 & $\mathrm{mg}$ \\
\hline $\mathrm{NaH}_{2} \mathrm{PO}_{4} \cdot \mathrm{H}_{2} \mathrm{O}$ & 10 & $\mathrm{mg}$ & $20 \mathrm{mg}$ & - & & - & \\
\hline Fe Sequestrene & 10 & $\mathrm{mg}$ & - & - & & - & \\
\hline $\mathrm{Na}_{2} \mathrm{SiO}_{3} \cdot 9 \mathrm{H}_{2} \mathrm{O}$ & 30 & $\mathrm{mg}$ & $30 \mathrm{mg} * *$ & 150 & $\mathrm{mg}$ & 30 & $\mathrm{mg}$ \\
\hline $\mathrm{K}_{2} \mathrm{HPO}_{4}$ & - & & - & 5 & $\mathrm{mg}$ & 20 & $\mathrm{mg}$ \\
\hline $\mathrm{NaCl}$ & - & & - & 18 & $\mathrm{~g}$ & - & \\
\hline $\mathrm{MgSO}_{4} \cdot 7 \mathrm{H}_{2} \mathrm{O}$ & - & & - & 5 & $\mathrm{~g}$ & - & \\
\hline $\mathrm{KCl}$ & - & & - & 0,6 & $\mathrm{~g}$ & - & \\
\hline $\mathrm{CaCl}_{2} \cdot 2 \mathrm{H}_{2} \mathrm{O}$ & - & & - & 367 & $\mathrm{mg}$ & - & \\
\hline TRIS & 500 & $\mathrm{mg} *$ & - & 1000 & $\mathrm{mg}$ & - & \\
\hline $\mathrm{FeC}_{3}$ & - & & - & 2,3 & $\mathrm{mg}$ & - & \\
\hline $\mathrm{ZnSO}_{4} \cdot 7 \mathrm{H}_{2} \mathrm{O}$ & 0,044 & $\mathrm{mg}$ & - & 0,66 & $\mathrm{mg}$ & 0,044 & $\mathrm{mg}$ \\
\hline $\mathrm{MnCl}_{2} \cdot 4 \mathrm{H}_{2} \mathrm{O}$ & 0,360 & $\mathrm{mg}$ & - & 4,3 & $\mathrm{mg}$ & 0,360 & $\mathrm{mg}$ \\
\hline $\mathrm{CoCl}_{2} \cdot 6 \mathrm{H}_{2} \mathrm{O}$ & 0,020 & $\mathrm{mg}$ & - & 12 & $\mu \mathrm{g}$ & 0,020 & $\mathrm{mg}$ \\
\hline $\mathrm{CuSO}_{4} \cdot 5 \mathrm{H}_{2} \mathrm{O}$ & 0,0196 & $\mathrm{mg}$ & - & 4,7 & $\mu \mathrm{g}$ & 0,0196 & $\mathrm{mg}$ \\
\hline $\mathrm{Na}_{2} \mathrm{MoO}_{4} \cdot 2 \mathrm{H}_{2} \mathrm{O}$ & 0,0126 & $\mathrm{mg}$ & - & - & & 0,0126 & $\mathrm{mg}$ \\
\hline $\mathrm{H}_{3} \mathrm{BO}_{3}$ & - & & - & 34 & $\mathrm{mg}$ & - & \\
\hline Tiamina & 0,200 & $\mathrm{mg}$ & - & 0,50 & $\mathrm{mg}$ & 0,200 & $\mathrm{mg}$ \\
\hline Biotina & 1,0 & $\mu \mathrm{g}$ & - & 1,0 & $\mu \mathrm{g}$ & 1,0 & $\mu \mathrm{g}$ \\
\hline Cianocobalamina & 1,0 & $\mu \mathrm{g}$ & - & 2,0 & $\mu g$ & 1,0 & $\mu g$ \\
\hline Ácido nicotínico & - & & - & 0,1 & $\mathrm{mg}$ & - & \\
\hline Pantotenato de cálcio & - & & - & 0,1 & $\mathrm{mg}$ & - & \\
\hline Ácido p-aminobenzóico & - & & - & 10 & $\mu \mathrm{g}$ & - & \\
\hline Inositol & - & & - & 5 & $\mathrm{mg}$ & -, & \\
\hline Ācido fólico & - & & - & 2 & $\mu \mathrm{g}$ & - & \\
\hline Timine & - & & - & 3 & $\mathrm{mg}$ & - & \\
\hline EDTA & - & & - & 30 & $\mathrm{mg}$ & - & \\
\hline Extrato de solo & - & & $50 \mathrm{ml}$ & - & & - & \\
\hline $\mathrm{H}_{2} \mathrm{O}$ do mar & 1000 & $\mathrm{ml}$ & $1000 \mathrm{ml}$ & - & & 750 & $\mathrm{~m} \ell$ \\
\hline $\mathrm{H}_{2} \mathrm{O}$ bi-destilada & - & & - & 1000 & $\mathrm{ml}$ & 250 & $\mathrm{~m} \ell$ \\
\hline Agar & - & & - & - & & 10 & $\mathrm{~g}$ \\
\hline
\end{tabular}

MEIOS "f" E " $f_{1}$ " (GUILlaRd \& RYTHER, 1962)

$\bar{A}$ água do mar, previamente filtrada, adicionou-se metassilicato de sódio $\left(\mathrm{Na}_{2} \mathrm{SiO}_{3} \cdot 9 \mathrm{H}_{2} \mathrm{O}\right)$ e $\mathrm{Fe}-\mathrm{Sequestrene}$ (Ethylene diamine tetra acetic acid, $13 \%$ de Fe: Geigy Industrial Chemicals), autoclavando-se em seguida. 
0 fosfato $\left(\mathrm{NaH}_{2} \mathrm{PO}_{4} \cdot \mathrm{H}_{2} \mathrm{O}\right)$ e o nitrato $\left(\mathrm{NaNO}_{3}\right)$ foram autoclavados separadamente, para evitar precipitações (Castel1vi, 1971).

Após um repouso de 24 horas em temperatura constante para que se dê a re-oxigenação, foram adicionados assepticamente o fosfato, o nitrato e os micronutrientes previamente preparados em solução. Só então, o meio estava pronto para receber os inóculos de algas.

0 meio " $f_{1}$ " difere do "f" por conter em sua composição determinada quantidade de TRIS (tris hidroximetil aminometano) que age como tampão entre $\mathrm{pH} 7,5-8,5$. Este meio pode ser adaptado com sucesso ao cultivo de espécies de água doce (diatomáceas, Scenedesmus sp., Selenastrum sp., Pediastrum sp., Ulothrix sp.etc.). Como essas espécies geralmente vivem em $\mathrm{pH}$ ligeiramente menor que o da água do mar, o TRIS deve ser substituído por outros "buffers" no tamponamento do $\mathrm{pH}$ do meio. Ethanolamina écido maleico são apropriados para pHs em torno de 7,0 .

- Solução de micronutrientes dos meios "f" e "f ${ }_{1}$

A solução de vitaminas e metais foi preparada na seguinte concentração:

$$
\begin{array}{rrrr}
\text { Tiamina } & \ldots \ldots \ldots & 200,0 & \mathrm{mg} \\
\text { Biotina } & \ldots \ldots \ldots & 0,001 & \mathrm{~g} \\
\text { Cianocobalamina } & \ldots \ldots \ldots & 0,001 & \mathrm{~g} \\
\mathrm{CuSO}_{4} \cdot 5 \mathrm{H}_{2} \mathrm{O} & \ldots \ldots \ldots & 19,6 & \mathrm{mg} \\
\mathrm{ZnSO}_{4} \cdot 7 \mathrm{H}_{2} \mathrm{O} & \ldots \ldots \ldots & 44,0 & \mathrm{mg} \\
\mathrm{CoCl}_{2} \cdot 6 \mathrm{H}_{2} \mathrm{O} & \ldots \ldots \ldots & 20,0 & \mathrm{mg} \\
\mathrm{MnCl}_{2} \cdot 4 \mathrm{H}_{2} \mathrm{O} & \ldots \ldots \ldots & 360,0 & \mathrm{mg} \\
\mathrm{Na}_{2} \mathrm{MoO}_{4} 2 \mathrm{H}_{2} \mathrm{O} & \ldots \ldots \ldots & 12,6 & \mathrm{mg}
\end{array}
$$

dissolvidos em 1000 ml de água bi-destilada e esterilizada, em ambiente asséptico. Um ml dessa solução adicionado a $1 \ell$ de água do mar, resultará nas concentrações originais dos micronutrientes da Tabela I. 
MEIO ERD-SCHREIBER (GROSS, 1937)

Em 1 l de água do mar esterelizada em autoclave, adiciona-se nitrato $\left(\mathrm{NaNO}_{3}\right)$ e fosfato $\left(\mathrm{NaH}_{2} \mathrm{PO}_{4} \cdot \mathrm{H}_{2} \mathrm{O}\right)$ já autoclavados e dissolvidos separadamente. Depois de 24 horas após a esterilização, adicionar 50 ml de extrato de solo (Fфyn, 1934, cit. in: Gross, 1937).

Quando o meio se destinar ao cultivo de diatomáceas, deve ser acrescentado metassilicato de sódio $\left(\mathrm{Na}_{2} \mathrm{SiO}_{3} \cdot 9 \mathrm{H}_{2} \mathrm{O}\right)$.

0 extrato de solo é feito utilizando-se de solos ricos ou em certos casos de sedimentos de mangue, baseando-se nas pesquisas feitas por Prakash et al. (1937). O extrato é preparado fervendo-se $1 \mathrm{~kg}$ de sedimento em 1 l de água destilada durante 30 minutos em autoclave, permanecendo depois em repouso durante três dias. Após este período, retira-se a parte líquida com cuidado e depois de filtrada em papel de filtro, esteriliza-se a $100^{\circ} \mathrm{C}$, deixando-se em repouso por quatro dias, em refrigerador. As partículas em suspensão decantam-se e o extrato estā pronto para ser utilizado.

MEIO ASP 2 (PROVASOLI, McLAUGHLIN \& DROOP, 1957)

Para facilitar a preparação deste meio, devem ser feitas previamente soluções-estoque dos vários constituintes.

Alíquotas dessas soluções-estoque são adicionadas à água bi-destilada, obtendo-se as concentrações originais da Tabela I. As concentrações das soluções-estoque bem como a quantidade de cada uma a ser adicionada à água bidestilada, são apresentadas na Tabela II.

Para se evitar precipitações, após a adição do silicato, baixa-se o pH para 7,2 antes da adição do fosfato (Provasoli et al., 1957).

MEIO SÓLIDO PARA ALGAS (MSA) (CHU, 1947 - MODIFICADO)

Este meio é preparado do seguinte modo: em $750 \mathrm{ml}$ de água do mar filtrada, adiciona-se $250 \mathrm{~m} \ell$ de água destilada e em seguida dissolve-se 0,100 g de 
TABELA 11 - Concentrações das soluções-estoque dos constituintes do meio $\mathrm{ASP}_{2}$ previamente preparados e suas quantidades a serem adicionadas a $822 \mathrm{ml}$ de $\mathrm{H}_{2} \mathrm{O}$ bi-destilada para se obter as concentrações originais da Tabela

\begin{tabular}{|c|c|c|c|}
\hline Nutrientes & \multicolumn{2}{|c|}{$\begin{array}{l}\text { Concentração } \\
\text { das soluçôes }\end{array}$} & $\begin{array}{l}\text { Quantidade das soluções } \\
\text { a ser adicionada a } \\
822 \text { ml de } \mathrm{H}_{2} \mathrm{O} \text { bi-destilada }\end{array}$ \\
\hline $\mathrm{NaC} \ell$ & 180 & $\mathrm{~g} / 1000 \mathrm{ml}$ & $100,0 \mathrm{ml}$ \\
\hline $\mathrm{MgSO}_{4} \cdot 7 \mathrm{H}_{2} \mathrm{O}$ & 200 & $\mathrm{~g} / 1000 \mathrm{ml}$ & $25,0 \mathrm{ml}$ \\
\hline $\mathrm{KC} \ell$ & 60 & $\mathrm{~g} / 1000 \mathrm{m \ell}$ & $10,0 \mathrm{ml}$ \\
\hline $\mathrm{CaCl}_{2} \cdot 2 \mathrm{H}_{2} \mathrm{O}$ & 36,7 & $\mathrm{~g} / 1000 \mathrm{ml}$ & $10,0 \mathrm{~m} \ell$ \\
\hline $\mathrm{NaNO}_{3}$ & 50 & $\mathrm{~g} / 1000 \mathrm{ml}$ & $1,0 \mathrm{ml}$ \\
\hline $\mathrm{K}_{2} \mathrm{HPO}_{4}$ & 5 & $\mathrm{~g} / 1000 \mathrm{~m} \ell$ & $1,0 \mathrm{ml}$ \\
\hline $\mathrm{Na}_{2} \mathrm{SiO}_{3} \cdot 9 \mathrm{H}_{2} \mathrm{O}$ & 15 & $\mathrm{~g} / 1000 \mathrm{ml}$ & $10,0 \mathrm{ml}$ \\
\hline TRIS & 10 & $\mathrm{~g} / 100 \mathrm{ml}$ & $10,0 \mathrm{ml}$ \\
\hline$B_{12}$ & 2 & $\mathrm{mg} / 100 \mathrm{ml}$ & $1,0 \mathrm{ml}$ \\
\hline EDTA & 3 & $\mathrm{~g} / 100 \mathrm{ml}$ & $1,0 \mathrm{ml}$ \\
\hline $\mathrm{FeC}_{3}$ & 230 & $\mathrm{mg} / 100 \mathrm{ml}$ & $1,0 \mathrm{ml}$ \\
\hline $\mathrm{ZnSO}_{4} \cdot 7 \mathrm{H}_{2} \mathrm{O}$ & 0,1655 & $\mathrm{~g} / 500 \mathrm{~m} \ell$ & $2,0 \mathrm{ml}$ \\
\hline $\mathrm{MnC}_{2} \cdot 4 \mathrm{H}_{2} \mathrm{O}$ & 430 & $\mathrm{mg} / 100 \mathrm{ml}$ & $1,0 \mathrm{ml}$ \\
\hline $\mathrm{CuSO}_{4} \cdot 5 \mathrm{H}_{2} \mathrm{O}$ & 470 & $\mathrm{mg} / 100 \mathrm{ml}$ & $1,0 \mathrm{m \ell}$ \\
\hline $\mathrm{CoC} \ell_{2} \cdot 6 \mathrm{H}_{2} \mathrm{O}$ & 12 & $\mathrm{mg} / 1000 \mathrm{~m} \ell$ & $1,0 \mathrm{ml}$ \\
\hline \multirow[t]{2}{*}{$\mathrm{H}_{3} \mathrm{BO}_{3}$} & 4,25 & $\mathrm{~g} / 250 \mathrm{ml}$ & \multirow[t]{9}{*}{$2,0 \mathrm{ml}$} \\
\hline & Solução d & de vitaminas & \\
\hline Tiamina $\mathrm{HCl}$ & $500 \mathrm{mg}$ ) & \multirow{8}{*}{$\begin{array}{c}1000 \mathrm{ml} \text { de } \\
\mathrm{H}_{2} \mathrm{O} \text { bi-des- } \\
\text { tilada }\end{array}$} & \\
\hline Ācido ni cotínico & $100 \mathrm{mg}$ & & \\
\hline Pantotenato de cálcio & $100 \mathrm{mg}$ & & \\
\hline Ācido p-aminobenzóico & $10 \mathrm{mg}$ & & \\
\hline Biotina & $1 \mathrm{mg}$ & & \\
\hline Inositol & $5000 \mathrm{mg}$ & & \\
\hline $\begin{array}{l}\text { Acldo follco } \\
\text { Timine }\end{array}$ & $2 \mathrm{mg}$ & & \\
\hline & 3000 ting & & \\
\hline
\end{tabular}


$\mathrm{Na}_{2} \mathrm{SiO}_{3} \cdot 9 \mathrm{H}_{2} \mathrm{O}, 0,020 \mathrm{~g}$ de $\mathrm{K}_{2} \mathrm{HPO}_{4}$ e $10 \mathrm{~g}$ de agar, tendo sido esterilizado em autoclave. Após a esterilização, adiciona-se $1 \mathrm{ml}$ de solução de micronutrientes (Guillard \& Ryther, 1962) ao meio ainda líquido, passando-se o mesmo para placas de Petri e tubos de ensaio inclinados, sob condições assépticas.

\section{MEIOS DE CULTURA DE BACTERIAS PARA TESTES DE ESTERILIDADE}

Os testes para verificar a presença ou não de bactérias, em culturas unialgais, foram feitos simultaneamente com três diferentes meios de cultura para bactérias.
a) "Triple sugar iron agar" (Difco)
b) Bacto peptona + agar (Spencer, 1952):

$\begin{array}{rc}\text { Bacto peptona } & 5,0 \mathrm{~g} \\ \text { Fosfato férrico } & 0,10 \mathrm{~g} \\ \text { Água do mar } & 750 \mathrm{m \ell} \\ \text { Água destilada } & 250 \mathrm{m \ell} \\ \text { Agar } & 15,0 \mathrm{~g}\end{array}$
c) Meio 1íquido (Castellvi, 1971)
Peptona (Difco) 10,0 g .
Água do mar $\quad 750 \mathrm{m \ell}$
Água destilada $250 \mathrm{m \ell}$

\section{COLETA}

As algas utilizadas neste trabalho foram coletadas nas regiões de Ubatuba e de Cananéia, com uma rede de plâncton com malha de $50 \mu \mathrm{m}$, para a obtenção das formas maiores do fitoplâncton e com garrafa de coleta "Van Dorn", para a obtenção do plâncton total.

Após as coletas, as amostras foram transferidas para recipientes de vidro neutro, jā contendo $50 \%$ de meio de cultura "f" e transportadas para o laboratório em caixas de "isopor", evitando-se choques de temperatura e luz. No laboratório, as amostras foram colocadas em incubadoras com luz e temperatura constantes, até o momento de se isolar as espécies desejadas, no máximo 24 horas após as coletas. 


\section{ISOLAMENTO}

Diferentes métodos foram empregados, dependendo das espécies a serem isoladas para o cultivo.

- Para o isolamento de células maiores que $50 \mu \mathrm{m}$ ou então espécies que formam cadeias, as amostras foram lavadas em filtros feitos com tubos de PVC de $17 \mathrm{~cm}$ de altura por $5 \mathrm{~cm}$ de diâmetro, com uma rede de "nylon" colocada em uma das extremidades, com poros de 25 ou $45 \mu$, dependendo das espécies presentes, para eliminar as formas menores do fitoplâncton e epífitas indesejadas que ficassem na rede de coleta.

A amostra foi passada pelo filtro em pequenas quantidades de cada vez e lavada várias vezes, com jatos de āgua do mar filtrada e esterilizada, proveniente do local de coleta, até a obtenção de uma quantidade suficiente de plâncton. Para a lavagem foi utilizada uma seringa tipo hipodérmica de 20 cc, não se empregando muita pressão no embôlo, para não danificar as células mais frāgeis; as lavagens foram repetidas vārias vezes em sala asséptica.

Apōs as lavagens nos "tubos-filtro", o material foi centrifugado vārias vezes (300 rpm-4 minutos), trocando-se de cada vez o meio centrifugado por meio novo e esterilizado. Com esse procedimento as formas menores do fitoplâncton, assim como grande quantidade de bactērias, fungos e protozoārios são eliminados facilitando a purificação posterior.

0 passo seguinte foi o exame de uma gota do material centrifugado ao microscópio e o isolamento das células ou cadeias, uma a uma, com um capilar de vidro (Pringsheim, 1946). A célula ou cadeia, depois de isolada, foi passada por vārias gotas de água do mar esterilizada e filtrada, e finalmente colocada em tubo de ensaio com $30 \mathrm{ml}$ de meio de cultura "f" não antes de se verificar bem, com a objetiva de maior aumento do microscópio, se havia ou não bactérias ou outro organismo contaminante no meio ou aderidos às células das algas.

Para garantia dos resultados foram isoladas separadamente em 15 tubos de ensaio, células de cada espécie desejada. 
- O material coletado com a garrafa "Van Dorn" foi usado para o isolamento de fitoflagelados e outras formas pequenas de fitoplâncton de acordo com o seguinte procedimento: foi retirada uma subamostra e transferida para um frasco com meio "f". O frasco foi colocado numa incubadora com luz e temperatura constantes $\left(3.000\right.$ lux e $25^{\circ} \mathrm{C} \pm 1^{\circ} \mathrm{C}$ ) por $3-4$ dias, quando verificouse um crescimento seletivo de värias formas de nanofitoplâncton entre as quais vários fitoflagelados e pequenas diatomáceas, obtendo-se assim, uma cultura mista (diversas formas do fitoplâncton). Desta cultura mista, passou-se cerca de $5 \mathrm{ml}$ para um tubo de ensaio (de $20 \mathrm{~cm}$ ) com $30 \mathrm{ml}$ de meio de cultura novo. 0 tubo foi coberto com papel preto até à superfície do líquido e inclinado cerca de $45^{\circ}$ em direção a uma fonte de 1 uz, por dois dias, induzindo-se assim o deslocamento de vários fitoflagelados pelo fototropismo positivo. Depois desse tempo, com uma pipeta tipo "Pasteur", foi retirada uma gota da superfície e diluída em 5 ml de meio "f" esterilizado repetindo-se novamente a fase do, isolamento ao microscópio, com capilar de vidro.

- Ainda em relação ao isolamento de fitoflagelados e outras espécies pequenas que ocorrem juntas, foi feita a separação de colônias crescendo sobre meio de cultura sólido para algas, em placas de Petri.

Após 6-8 dias de semeadura de algumas gotas de cultura mista nas placas, notou-se o crescimento de várias colônias de algas diferenciáveis a olho nü, pela coloração. Depois de identificadas ao microscópio, foram separadas com alças de platina e inoculadas em meio de cultura líquido "Erd-Schreiber" ou meio "f".

\section{PURIFICAÇÃO DE CULTURA UNIALGAL - OBTENÇÃO DE CULTURA AXENICA}

Após a obtenção de culturas unialgais, o objetivo seguinte foi a completa eliminação das bactérias dessas culturas. Empregou-se para isso os seguintes métodos: lavagem das células, reisolamento, mistura de antibióticos e exposição a radiações U.V.

\section{LAVAGEM}

A lavagem das células de culturas unialgais foi empregada como um tratamento prévio para obtenção de culturas axênicas. 
- Lavagem por meio de filtração

Para culturas unialgais de células grandes (Coscinodiscus sp., Dity lum brightwellii) ou que formam cadeias (Skeletonema costatum, Chaetoceros wighami, Melosira moniliformis etc.), usou-se o método de lavagens sucessivas sobre telas de "nylon", com poros de $25 \mu \mathrm{m}$ (Paredes, 1967-1968). Para tanto, utilizou-se os mesmos tubos de PVC empregados no processo de isolamento.

Sob câmara asséptica (Fig. 1) as células da cultura a ser tratada (sempre na fase exponencial), foram passadas pelo "tubo-filtro" e lavadas com jatos de água do mar esterilizada e filtrada, forçando as bactérias contaminantes a passarem pelos poros da rede. Logo após, as células retidas na rede foram inoculadas em frascos de culturas com meio novo " $f_{1}$ " ou $\mathrm{ASP}_{2}$ e levadas para incubar por 3-5 dias em temperaturas relativamente baixas $\left( \pm 15^{\circ} \mathrm{C}\right)$ e intensidades luminosas não menores do que 3.000 lux. Após esse período de incubação as células, jã então em fase exponencial, foram novamente lavadas e postas para incubar nas mesmas condições de temperatura e luz. Esse tipo de lavagem repetiu-se em média três vezes para cada espécie a ser tratada.

\section{- Lavagem por meio de centrifugação}

Quando a cultura a ser tratada era de células muito pequenas não formando cadeias, e por isso de dificílima retenção no filtro, como Phaeodactylum tricormutum, Chlorella sp., Nitzchia closterium, fitoflagelados etc., foi empregado o método de lavagem das células por centrifugação (Pringsheim, 1946; Balantine, 1953).

As lavagens foram feitas através de vārias centrifugações da cultura na fase exponencial, trocando-se o meio centrifugado por meio novo esterilizado, variando-se a velocidade de centrifugação de um máximo (4.000 rpm) para um mínimo (2.000 rpm). Alcançada a velocidade mínima para a precipitação das algas, depois de em média quatro centrifugações, as células foram inoculadas em meio " $f_{1}$ " esterilizado e incubadas sob condições de luz e temperatura como no ítem anterior. Ainda como no caso anterior, o processo lavagem-incubação-lavagem para cada espécie a ser tratada, repetiu-se várias vezes. 


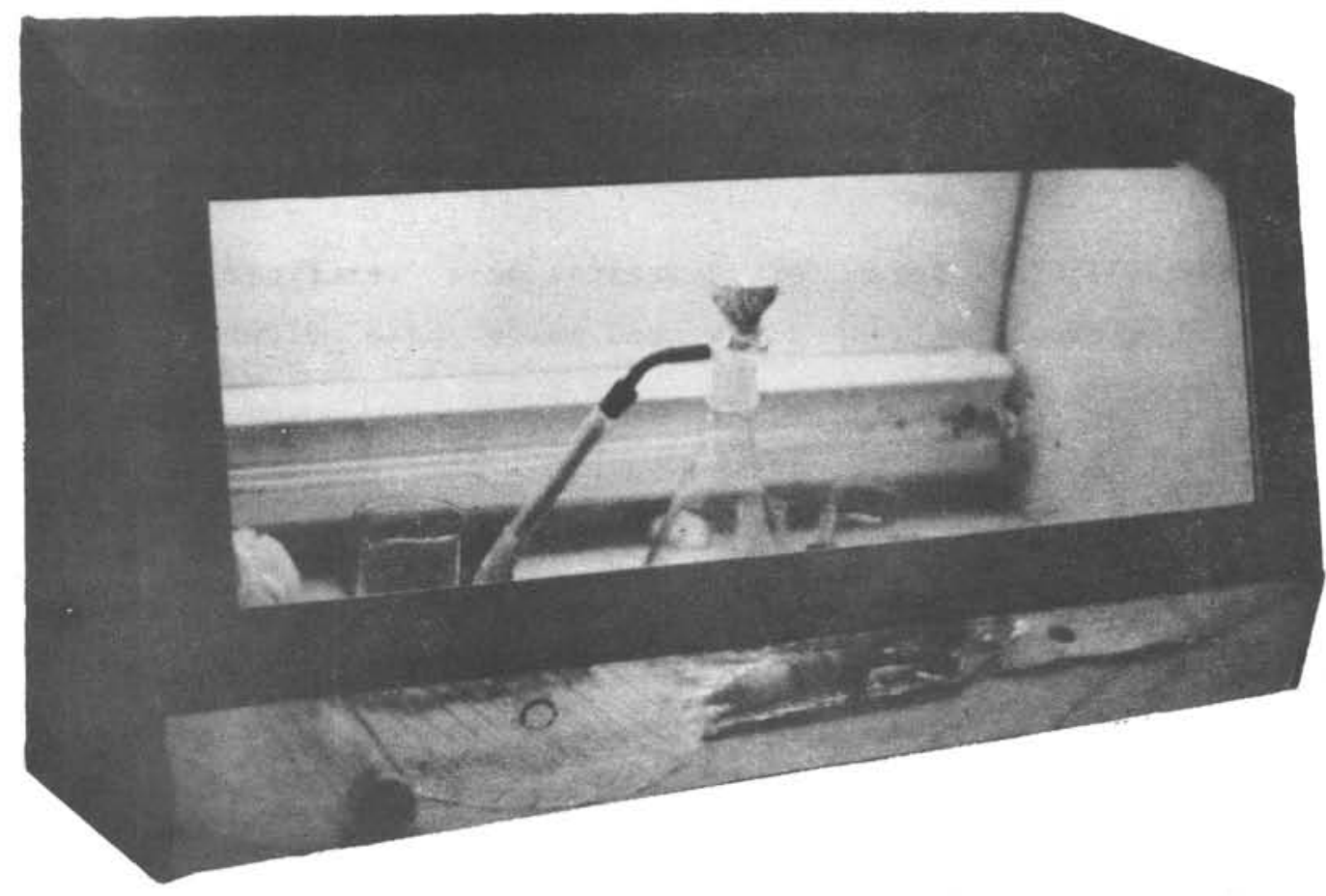

Fig. 1-Câmara assēptica com luz ultra-violeta (três lâmpadas de $30 \mathrm{~W}$ cada).

\section{REIS OLAMENTO}

Este método nada mais é do que a lavagem sob o microscópio de uma única célula ou cadeia, em gotas de meio esterilizado (Pringsheim, 1946; Chu, 1947; Kain \& Fogg, 1960; Guillard \& Ryther, 1962; Paredes, 1967-1968). As células ou cadeias a serem reisoladas eram sempre provenientes de culturas na fase exponencial, previamente lavadas através dos métodos já citados e com níveis mínimos de contaminação.

Com uma pipeta esterilizada, retirou-se assepticamente cerca de $1 \mathrm{ml}$ da cultura a ser purificada, a qual foi diluida em $20 \mathrm{~m} \ell$ de água do mar esterilizada e filtrada em filtro "Millipore-HA". Após homogeneizada a suspensão de células, retirou-se uma gota e ao microscópio, em sala asséptica, procedeu-se ao reisolamento com capilares de vidro, seguindo-se a metodologia já descrita para o isolamento (pägina 312). 
As células, ou cadeias de células, isoladas, foram inoculadas individualmente em um tubo de ensaio com meio " $f_{1}$ " ou $A_{S S} P_{2}$ e incubadas a $20^{\circ} \mathrm{C} \pm 1{ }^{\circ} \mathrm{C}$ e 3.000 lux. Para cada espécie a ser purificada foram sempre inoculados dez tubos.

Depois de 3-5 dias foram feitos testes para verificar se as culturas eram ou não axênicas, com três diferentes meios para culturas de bactérias, simultaneamente.

\section{USO DE ANTIBIÓTICOS}

Um outro método testado para a obtenção de culturas axênicas, foi o tratamento de culturas unialgais, com antibióticos (Fish, 1950; Spencer, 1952; Guillard \& Ryther, 1962; Droop, 1967; Paredes, 1967-1968; Quraishi, 1968; Castellvi, 1971).

Foi utilizada uma mistura dos seguintes antibióticos, na forma de sais puros: cloranfenico1 levógiro (Carlo Erba); sulfato de estreptomicina (Fontoura-Wyeth, lotes 032-U e 620-U); penicilina G-potássica (FontouraWyeth, lote 787-U); sulfato de neomicina (Bristol, lote $\operatorname{Tr} 1353-103$ ); actidione (cicloeximide) (Upjhon).

A escolha dos antibióticos testados neste trabalho foi baseada nas indicações bibliográficas, na facilidade de sua aquisição e sua ação predominante: neomicina e estreptomicina têm ação sobre germes gram negativos; penicilina age em gram positivos; cloranfenicol é de amplo espectro de ação e o actidione é um fungicida. A penicilina e a estreptomicina, além de bactericidas, são tambēm bacteriostāticas (Mingoia, 1967).

O tratamento com mistura de antibióticos foi precedido de testes preliminares, expondo-se as células a cada antibiótico isoladamente. Com este procedimento foi possível conhecer qual a concentração máxima do antibiōtico a que a espécie resistiria sem sofrer danos aparentes e qual a concentração ótima de cada antibiōtico na mistura. Estes testes foram feitos expondo-se as células da cultura unialgal, na fase exponencial de crescimento, as concentrações crescentes do antibiótico em tubos de ensaio com $15 \mathrm{ml}$ de meio " $f_{1}$ " por cinco dias a $25^{\circ} \mathrm{C} \pm 1{ }^{\circ} \mathrm{C}$ e 3.000 lux (Tab. III). 
TABELA III - Concentrações mäximas (mg/ml) dos värios antibiöticos a que as espécies ci tadas resisti ram, sem danos aparentes, após exposição de cinco dias em $25^{\circ} \mathrm{C}$ e 3.000 lux

\begin{tabular}{|c|c|c|c|c|}
\hline Algas & Penicilina & Estreptomicina & Cloranfenicol & Neomicina \\
\hline $\begin{array}{c}\text { Skeletonema } \\
\text { costatum }\end{array}$ & 0,90 & 0,20 & 0,10 & 0,25 \\
$\begin{array}{c}\text { Phaeodactylum } \\
\text { tricornutum }\end{array}$ & 1,00 & 1,40 & 0,10 & $0,25^{+}$ \\
$\begin{array}{c}\text { Chaetoceros } \\
\text { wighami }\end{array}$ & 0,90 & 0,20 & 0,10 & $0,25^{+}$ \\
Fitoflagelados & $1,40^{+}$ & $1,40^{+}$ & 0,16 & $0,25^{+}$ \\
\hline$+=$ concentração máxima testada.
\end{tabular}

- Preparo da mistura de antibióticos

Com base nos testes preliminares antes citados, preparou-se uma solução das seguintes quantidades de antibióticos, dissolvidos em $20 \mathrm{m \ell}$ de água bidestilada e esterilizada:

$$
\begin{aligned}
& 20 \mathrm{mg} \text { de cloranfenicol } \\
& 50 \mathrm{mg} \text { de estreptomicina } \\
& 100 \mathrm{mg} \text { de penicilina } \\
& 50 \mathrm{mg} \text { de neomicina } \\
& 5 \mathrm{mg} \text { de actidione }
\end{aligned}
$$

A solução foi filtrada em filtro "Millipore-VF" (10 $\mu \mathrm{m})$ e utilizada imediatamente após o preparo.

- Emprego da mistura de antibióticos

As células em fase exponencial de crescimento (previamente lavadas) da cultura unialgal a ser tratada, foram expostas a concentrações crescentes da mistura de antibióticos, em uma bateria de 16 tubos de ensaio (de $20 \times 2 \mathrm{~cm}$ ). Em cada tubo colocou-se $20 \mathrm{ml}$ de cultura, menos a alíquota correspondente à solução de antibióticos a ser adicionada a cada tubo (Tab. IV). 
TABELA IV - Preparo da bateria de tubos com os antibiöticos e sua concentração em cada tubo mais a quantidade de cultura

\begin{tabular}{|c|c|c|c|c|c|c|c|c|c|c|c|c|}
\hline & Tubos & 0 & 1 & II & III & IV & $\mathrm{v}$ & VI & VII & VIII & $\ldots$ & XVI \\
\hline \multirow{4}{*}{ 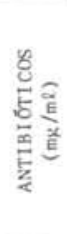 } & Cloranfenicol & - & 0,012500 & 0,025000 & 0,037500 & 0,050000 & 0,062500 & 0,075000 & 0,087500 & 0,100000 & $\ldots$ & 0,200000 \\
\hline & Penicilina & - & 0,062500 & 0,125000 & 0,187500 & 0,250000 & 0,312500 & 0,375000 & 0,437500 & 0,500000 & $\ldots$ & 1,000000 \\
\hline & Neomicina & - & 0,031250 & 0,062500 & 0,093750 & 0.125000 & 0,156250 & 0,187500 & 0,218750 & 0.250000 & $\ldots$ & 0,500000 \\
\hline & Actidione & - & 0.003125 & 0,006250 & 0,009375 & 0,012500 & 0,015625 & 0,018750 & 0,021875 & 0,025000 & $\ldots$ & 0,050000 \\
\hline
\end{tabular}

Depois de 12 e 24 horas de exposição das células aos antibióticos, a $25^{\circ} \mathrm{C} \pm 1{ }^{\circ} \mathrm{C}$ e $3.0001 \mathrm{ux}$, foram retiradas algumas gotas de cada tubo e, em condições assépticas, inoculadas em frascos de cultura com meio " $f_{1}$ " esterilizado, sem antibióticos, para se verificar a viabilidade das células após o tratamento.

Paralelamente, foram feitos testes de esterilidade para cada tubo da bateria de antibióticos, utilizando-se três diferentes meios para bactérias (página 311).

0 efeito dos antibióticos no crescimento das algas foi avaliado por meio de comparação das curvas de crescimento de célula de Phaeodactylum tricormutum tratadas por 24 horas à concentração III (tubo III) e passadas logo após para o meio sem antibióticos, com células provenientes do tubo 0 , sem antibióticos .

\section{EXPOSIÇÃO DAS ALGAS A RADIAÇÕES U.V.}

Outro método testado para a purificação das culturas de algas foi o emr prego de radiações ultra-violeta sobre suspensões de células (Zobel1 \& Long, 1938; Gerloff et al., 1950; Paredes, 1967-1968).

0 teste consistiu em se expor a uma fonte de luz ultra-violeta, suspensões de células em uma placa de Petri, formando um fino filme de poucos milímetros. A fonte de luz U.V. era formada por duas lâmpadas GE de 30 W (G30T8). 
A distância entre as lâmpadas e a suspensão de células foi de $50 \mathrm{~cm}$. 0 tempo de exposição foi de $2,4,6,8,10,15$ e 20 minutos. Depois de cada tempo de exposição foram tiradas amostras (algumas gotas) assepticamente, para tubos com cerca de $20 \mathrm{ml}$ de meio " $\mathrm{f}_{1}$ " esterilizado, para verificar-se a viabilidade das células algais. Simultaneamente algumas gotas foram inoculadas em meios de cultura para bactérias, para testes de esterilidade.

\section{MANUTENÇÃO DE CULTURAS ALGAIS EM ESTOQUE}

Para a manutenção de culturas unialgais não axênicas, foram utilizados os meios: Erd-Schreiber "f" e "f $f_{1}$ " de Guillard \& Ryther (1962) e meio sólido de Chu (modif.).

As culturas unialgais axênicas foram estocadas em meio " $f_{1}$ " e em $\mathrm{ASP}_{2}$. Os estoques foram mantidos a $15-20^{\circ} \mathrm{C}$ e 2.000 lux.

\section{MANUTENÇÃO DE ESTOQUES EM BAIXAS TEMPERATURAS}

Foi testada também a manutenção de estoques de culturas em meio " $f_{1}$ " na fase exponencial de värias espécies em refrigerador, no escuro e a $4^{\circ} \pm 1^{\circ} \mathrm{C}$ (Umebayashi, 1972). Cada espécie foi subdividida em vários tubos de "pyrex" de $20 \mathrm{ml}$ com tampa de rosca e, diariamente, um tubo era retirado e inoculado a $25^{\circ} \mathrm{C} \pm 1{ }^{\circ} \mathrm{C}$ e 2.500 lux para teste de viabilidade. As culturas somente recebiam luz ocasionalmente quando a porta do refrigerador era aberta.

\section{RESULTADOS}

\section{SOLAMENTO}

Pelo método de lavagens em filtros e posterior separação com capilares de vidro ao microscópio (página 312), foram isoladas e mantidas em culturas unialgais as seguintes espécies: 


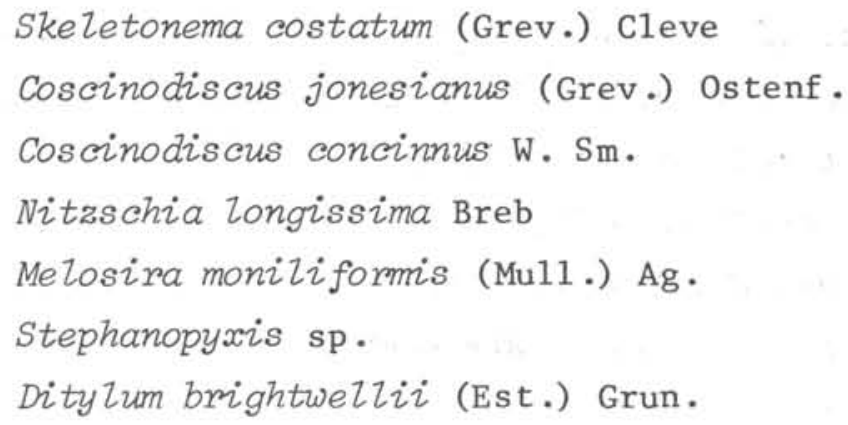

Empregando-se o fototropismo positivo como método de separação de fitoflagelados (página 313), foram isoladas e mantidas em culturas unialgais duas espécies de fitoflagelados fotoautotróficos, não identificadas.

Pelo método de inoculação de gotas de culturas mistas emplacas de "Petri" com meio sólido para algas (página 313), foram isoladas e mantidas em culturas unialgais as. seguintes espēcies:

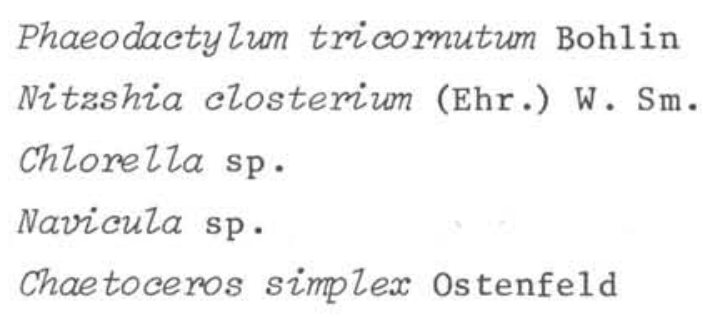

e uma espécie de cianofícea (não colonial), não identificada.

\section{PURI FI CAÇÃO}

\section{LAVAGENS}

Com o emprego das lavagens como um tratamento de purificação, obteve-se resultados satisfatórios. Culturas unialgais de Skeletonema costatum, Chaetoceros wighami, Melosira moniliformis e Coscinodiscus concinnus intensamente contaminadas por bactérias, apresentaram baixos níveis de contaminação quando tratadas pelo método de lavagem por filtração (página 314), sendo que algumas subculturas de Skeletonema costatum, Melosira moniliformis e Coscinodiscus concinnus deram respostas negativas aos testes de esterilização, até seis dias depois do tratamento. 
Pelo método de lavagens por meio de centrifugações (página 314) foram obtidas culturas de Phaeodactylum tricormutum que deram respostas negativas aos testes de esterilidade após seis subculturas sucessivas com lavagens a cada 3-4 dias. Foram também obtidas culturas de Chlorella sp. e fitoflagelados com níveis de contaminação incipientes após 10-12 dias de cultivo, aumentando, no entanto, o número de bactérias a partir desta idade. As observações comparativas das contaminações foram feitas pelo número de colônias nos meios sólidos, e pela turbidez no meio líquido.

\section{REISOLAMENTO}

Foram obtidas culturas unialgais axênicas a partir de células tratadas pelo método de reisolamento, com células de Skeletonema costatum, Phaeodactylum tricomutum e Melosira moniliformis em dez tubos para cada espécie. Cerca de $40 \%$ desses tubos originaram culturas que deram respostas negativas aos testes de presença de bactérias, feitos nos três meios específicos.

\section{ANTIBIŌTICOS}

Quando as células são tratadas com antibióticos apresentam indícios de que estes afetam a sua fisiologia. Foram observadas alterações morfológicas nas células de Phaeodactylum tricomutum pois quase $100 \%$ das mesmas, após o tratamento, apresentavam-se sob a forma oval, forma esta que normalmente aparece em pequenas quantidades toda vez que são mudadas as condições de cultura, como variação de temperatura ou mudança de meio de cultura. Nas outras espécies tratadas com concentrações viáveis, as células apresentavam-se descoradas e quando transferidas para meio sem antibióticos a porcentagem de células que degeneravam era grande, com o conseqüente aumento da duração da fase "lag". Esse fato pode ser verificado com Phaeodactylum tricornutum tratada com antibióticos da concentração III (Tab. IV). A fase "lag" da curva de crescimento das culturas do tubo o (sem antibióticos) foi de apenas três dias, enquanto que aquela de culturas tratadas com antibióticos foi de nove dias (Fig. 2). 


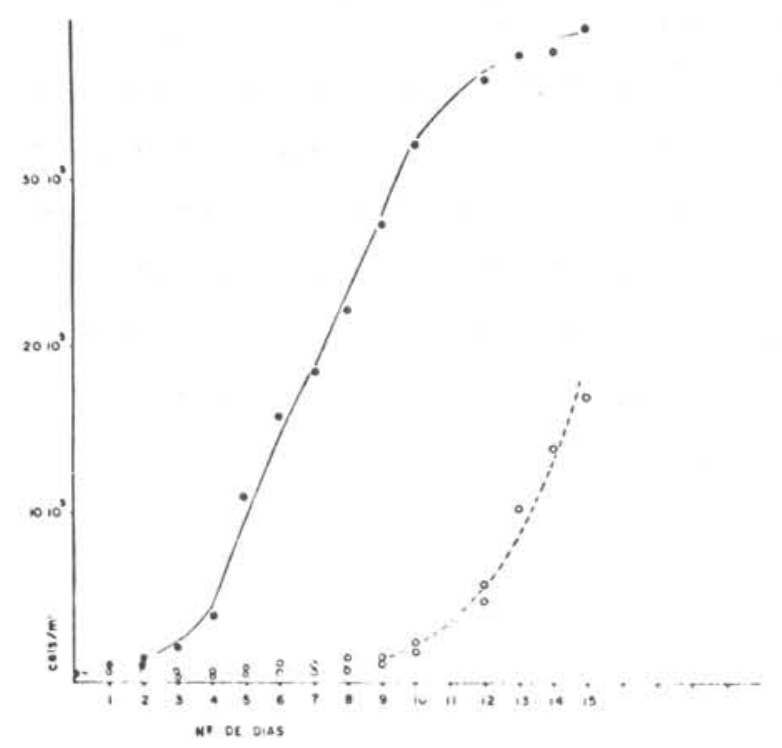

o-----o depois de 24 horas de exposição à concentração 111 da mistura de antibióticos

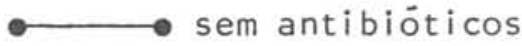

Fig. 2 - Efeito dos antibiöticos na curva de crescimento (cels/ $\mathrm{ml)}$ de Phaeodactylum tricormutum $\left(25^{\circ} \mathrm{C}\right.$ e $\left.2.500 \mathrm{lux}\right)$.

Na Tabela V são apresentados os resultados de cinco réplicas do experimento de exposição de quatro espécies do fitoplâncton por 12 horas e 24 horas à mistura de antibióticos.

As concentrações ótimas de antibiōticos encontradas foram aquelas dos tubos III e IV para diatomáceas e IV, V e VI para fitoflagelados (ver concentrações na Tab. IV).

0 número de culturas axênicas conseguidas em cinco experimentos, nas me1hores concentrações, ē apresentado na Tabela VI.

\section{TRATAMENTO COM RADIAÇÕES ULTRA-VIOLETA}

Este método de purificação não se apresentou favorável para a obtenção de culturas axênicas. Células de Skeletonema costatum não resistiram a mais do que quatro minutos de exposição às radiações e Phaeodactylum tricormutum e Chaetoceros wighami não resistiram a dois minutos. Fitoflagelados, no entanto, resistiram atē 15 minutos de exposição às radiações e suas bactérias contaminantes apenas a oito minutos, originando com isso culturas axênicas. No entanto, em algumas culturas de fitoflagelados, após o tratamento, ocorreu grande crescimento de fungos (Tab. VII). 
TABELA V - Viabilidade de quatro espécies do fitoplâncton em cultura e de suas bactërias contaminantes apös a exposição por 12 e 24 horas a concentrações crescentes da mistura de antibiöticos (freqüência de cinco réplicas do experimento).

\begin{tabular}{|c|c|c|c|c|c|c|c|c|c|c|c|c|}
\hline & Tubos & 0 & I & II & III & IV & v & VI & VII & VIII & $\ldots$ & XVI \\
\hline \multicolumn{2}{|c|}{$\begin{array}{l}\text { Mistura de antibióticos } \\
\text { em cada tubo (ml) }\end{array}$} & 0,00 & 0,25 & 0,50 & 0,75 & 1,00 & 1,25 & 1,50 & 1,75 & 2,00 & $\cdots$ & 4,00 \\
\hline \multirow[b]{2}{*}{$12 \mathrm{~h}$} & S. costatum & $5^{+}$ & $5^{+}$ & $5^{+}$ & $4^{+}$ & $3^{+}$ & $5^{-}$ & $5^{-}$ & $5^{-}$ & $5^{-}$ & $\ldots$ & $5^{-}$ \\
\hline & Bactérias & $5^{+}$ & $5^{+}$ & $5^{+}$ & $2^{-}$ & $3^{-}$ & $5^{-}$ & $5^{-}$ & $5^{-}$ & $5^{-}$ & $\cdots$ & $5^{-}$ \\
\hline \multirow[b]{2}{*}{$24 \mathrm{~h}$} & S. costatum & $5^{+}$ & $5^{+}$ & $5^{+}$ & $2^{+}$ & $1^{+}$ & $5^{-}$ & $5^{-}$ & $5^{-}$ & $5^{-}$ & $\ldots$ & $5^{-}$ \\
\hline & Bactérias & $5^{+}$ & $5^{+}$ & $5^{+}$ & $3^{-}$ & $4^{-}$ & $5^{-}$ & $5^{-}$ & $5^{-}$ & $5^{-}$ & $\ldots$ & $5^{-}$ \\
\hline \multirow[b]{2}{*}{$12 \mathrm{~h}$} & P. tricornutwo & $5^{+}$ & $5^{+}$ & $5^{+}$ & $5^{+}$ & $4^{+}$ & $1^{+}$ & $5^{-}$ & $5^{-}$ & $5^{-}$ & $\ldots$ & $5^{-}$ \\
\hline & Bactérias & $5^{+}$ & $5^{+}$ & $5^{+}$ & $2^{-}$ & $3^{-}$ & $5^{-}$ & $5^{-}$ & $5^{-}$ & $5^{-}$ & $\ldots$ & $5^{-}$ \\
\hline \multirow[b]{2}{*}{$24 \mathrm{~h}$} & P. tricormutum & $5^{+}$ & $5^{+}$ & $5^{+}$ & $3^{+}$ & $3^{+}$ & $5^{-}$ & $5^{-}$ & $5^{-}$ & $5^{-}$ & $\ldots$ & $5^{-}$ \\
\hline & Bactérias & $5^{+}$ & $5^{+}$ & $5^{+}$ & $3^{-}$ & $4^{-}$ & $5^{-}$ & $5^{-}$ & $5^{-}$ & $5^{-}$ & $\ldots$ & $5^{-}$ \\
\hline \multirow[b]{2}{*}{$12 \mathrm{~h}$} & c. wighami & $5^{+}$ & $5^{+}$ & $5^{+}$ & $3^{+}$ & $3^{+}$ & $5^{-}$ & $5^{-}$ & $5^{-}$ & $5^{-}$ & $\ldots$ & $5^{-}$ \\
\hline & Bactérias & $5^{+}$ & $5^{+}$ & $5^{+}$ & $1^{-}$ & $2^{-}$ & $5^{-}$ & $5^{-}$ & $5^{-}$ & $5^{-}$ & $\ldots$ & $5^{-}$ \\
\hline \multirow[b]{2}{*}{$24 \mathrm{~h}$} & c. wigham & $5^{+}$ & $5^{+}$ & $5^{+}$ & $1^{+}$ & $5^{-}$ & $5^{-}$ & $5^{-}$ & $5^{-}$ & $5^{-}$ & $\ldots$ & $5^{-}$ \\
\hline & Bactérias & $5^{+}$ & $5^{+}$ & $5^{+}$ & $2^{-}$ & $4^{-}$ & $5^{-}$ & $5^{-}$ & $5^{-}$ & $5^{-}$ & $\ldots$ & $5^{-}$ \\
\hline \multirow[b]{2}{*}{$12 \mathrm{~h}$} & Fi tof lagelados & $5^{+}$ & $5^{+}$ & $5^{+}$ & $5^{+}$ & $5^{+}$ & $5^{+}$ & $3^{-}$ & $5^{-}$ & $5^{-}$ & $\cdots$ & $5^{-}$ \\
\hline & Bactérias & $5^{+}$ & $5^{+}$ & $5^{+}$ & $3^{-}$ & $4^{-}$ & $5^{-}$ & $5^{-}$ & $5^{-}$ & $5^{-}$ & $\ldots$ & $5^{-}$ \\
\hline \multirow[b]{2}{*}{$24 \mathrm{~h}$} & Fit tof lage lados & $5^{+}$ & $5^{+}$ & $5^{+}$ & $5^{+}$ & $5^{+}$ & $5^{+}$ & $3^{+}$ & $5^{-}$ & $5^{-}$ & $\ldots$ & $5^{-}$ \\
\hline & Bactérias & $5^{+}$ & $5^{+}$ & $5^{+}$ & $3^{-}$ & $4^{-}$ & $5^{-}$ & $5^{-}$ & $5^{-}$ & $5^{-}$ & $\ldots$ & $5^{-}$ \\
\hline
\end{tabular}

\begin{tabular}{|l|c|c|c|c|c|c|}
\hline \multirow{2}{*}{ Espécies } & \multirow{2}{*}{$\begin{array}{c}\text { Tempo de } \\
\text { exposição } \\
(\mathrm{h})\end{array}$} & \multicolumn{5}{|c|}{ Concentrações (tubos) } \\
\cline { 3 - 7 } & 12 & III & IV & V & VI & VII \\
\hline \multirow{2}{*}{ S. costatum } & 24 & 2 & 3 & 0 & 0 & 0 \\
& 12 & 2 & 3 & 1 & 0 & 0 \\
\hline P. tricormutum & 24 & 3 & 2 & 0 & 0 & 0 \\
\hline C. wighami & 12 & 1 & 1 & 0 & 0 & 0 \\
& 24 & 1 & 0 & 0 & 0 & 0 \\
\hline \multirow{2}{*}{ Fitof1agelados } & 12 & 3 & 4 & 5 & 3 & 0 \\
& 24 & 3 & 4 & 5 & 3 & 0 \\
\hline
\end{tabular}

\section{TABELA VI}

Freqüência dos resultados positivos (culturas axênicas) emcinco experimentos nos tubos com as concentrações de antibiōticos, mais favoräveis em 12 e 24 horas de exposição 
TABELA VII - Exposição de culturas unialgais de quatro espécies a radiações ultra-violeta em intervalos de 2-20 min. A viabilidade foi verificada depois de 20 dias de incubação, após a exposição

\begin{tabular}{|c|c|c|c|c|c|c|c|}
\hline \multirow{2}{*}{ Espécies } & \multicolumn{7}{|c|}{ Tempo de exposição em minutos } \\
\hline & 2 & 4 & 6 & 8 & 10 & 15 & 20 \\
\hline $\begin{array}{r}\text { Skeletonema } \\
\text { costatum }\end{array}$ & + & + & - & - & - & - & - \\
\hline Bactērias & + & + & + & + & + & - & - \\
\hline $\begin{array}{l}\text { Phaeodactylum } \\
\text { tricornutum }\end{array}$ & + & - & - & - & - & - & - \\
\hline Bactērias & + & + & + & + & + & - & - \\
\hline $\begin{array}{l}\text { Chaetoceros } \\
\text { wighami }\end{array}$ & + & - & - & - & - & - & - \\
\hline Bactērias & + & + & + & + & + & - & - \\
\hline Fitoflagelados & + & + & + & + & + & + & - \\
\hline Bactérias & + & + & + & + & - & - & - \\
\hline
\end{tabular}

\section{MANUTENÇÃO DAS CULTURAS}

Culturas não axênicas de várias espécies isoladas neste trabalho, apresentaram inóculos viāveis após sua manutenção ininterruptamente por:

a) 210 dias para PhaeodactyZum tricomutum, mantida em meios $\mathrm{ASP}_{2}$, "f", " $f_{1}$ ", Erd-Schreiber e meio sólido para algas (MSA), a $20^{\circ} \mathrm{C}$ e $2.000-2.500$ lux de iluminação contínua.

b) 60 dias para Skeletonema costatum, mantida em meios "f", " $f_{1}$ " e $\mathrm{ASP}_{2}$ a $20^{\circ} \mathrm{C}$ e 2.000-2.500 lux e iluminação contínua.

c) 180 dias para Chlorella sp., mantida em meios "f", "f $f_{1}$ ", $\mathrm{ASP}_{2}$ e meio sólido para algas (MSA), a $20^{\circ} \mathrm{C}$ e $2.000-2.500$ lux e iluminação contínua. 
d) 60 dias para Chaetoceros wighami, mantida em meios "f" e "f $f_{1}$ ", a $20^{\circ} \mathrm{C}$ e 2.000-2.500 lux e iluminação contínua.

e) 180 dias para Melosira moniliformis, mantida em meios "f", "f $f_{1}$ ", $\operatorname{ASP}_{2}$ e Erd-Schreiber, a $20^{\circ} \mathrm{C}$ e $2.000-2.500$ lux e iluminação contínua.

f) 180 dias para fitoflagelados, mantidos em meios "f", " $f_{1}$ ", $\mathrm{ASP}_{2}$ e ErdSchreiber, e 120 dias em meio sólido para algas (MSA), a $20^{\circ} \mathrm{C}$ e $2.000-$ 2.500 lux e iluminação contínua.

g) 30 dias para Coscinodiscus concinnus, Coscinodiscus jonesianus e Ditylum brightwelliii em meio sólido para algas (MSA), a $20^{\circ} \mathrm{C}$ e $2.000-2.500$ lux e iluminação contínua.

\section{MANUTENÇÃO DE CULTURAS EM BAIXAS TEMPERATURAS E NO ESCURO}

A manutenção de estoques no escuro e em baixas temperaturas apresentouse favorável para iniciar novas culturas em condições normais de cultivo, atē depois de 30 dias no escuro e a baixas temperaturas, de Phaeodactylum tricornutum e fitoflagelados fotoautotróficos (Chlamydomonas sp.). No emtanto, as demais espécies testadas, como Skeletonema costatum, Chaetoceros wighami, C. simplex, Nitzschia Zongissima, N. Closterium e Navicula sp., não apresentaram viabilidade quando transferidas para $20-25^{\circ} \mathrm{C}$ e $2.5001 \mathrm{ux}$. Porém, as células apresentaram-se em bom estado de conservação morfológica até depois de mais de 12 meses no refrigerador, o que propicia um bom método de conservação de massas de algas para fins de alimentação de certos animais em aqüicultura, como larvas de camarão, Artemia etc.

\section{DISCUSSÃO}

\section{ISOLAMENTO}

0 isolamento de espécies do fitoplâncton deve ser iniciado logo após a coleta ou no máximo dentro de 24 horas. Após esse período, a morte de organismos, principalmente de indivíduos do zooplâncton favorece, por aumento de 
substrato, o crescimento de protozoários muito pequenos, bactérias e fungos que dificultam o isolamento das espécies desejadas. A morte desses organismos provoca, também, alterações químicas em um volume limitado de água. A mineralização de matéria orgânica morta favorece o florescimento de uma população diferente da coleta, geralmente espécies muito pequenas, com altas taxas de crescimento.

0 emprego de capilares de vidro para o isolamento de espécies do fitoplâncton sob o microscópio, empregado provavelmente pela primeira vez por Mique1 (1890-1892, cit in: Pringsheim, 1946), mostrou ter um rendimento satisfatório em trabalhos rotineiros de laboratório, para células de tamanho relativamente grande ou que formam cadeias como Skeletonema costatum, Melosira moniliformis etc. Uma maioria significativa das células das várias espécies isoladas (sete entre dez em média) apresentaram viabilidade, originando culturas unialgais.

A grande vantagem deste método consiste no fato de, desde que a operação seja feita sob o microscópio, poder-se escolher a espécie de interesse e entre as células da mesma, escolher-se as que se apresentam em condições favoráveis para o início de uma cultura. Além disso, sob o microscópio pode-se evitar células que estejam com outros organismos aderidos a elas (p.ex. Vor ticella sp.), ou pipetar juntamente com a espécie desejada, protozoários e outras algas de tamanho reduzido. Diminui-se, tambēm, a possibilidade de um crescimento seletivo intenso de bactérias, quando da transferência da alga para o frasco de cultura.

Entretanto, a obtenção de culturas unialgais axênicas sem outros processos intermediārios, não foi conseguida nas värias tentativas feitas. Apesar de se evitar a pipetagem de bactérias junto com as algas, lavando-se a célula isolada em várias gotas de meio estéril, algumas bactérias não notadas no ato do isolamento, foram separadas juntamente com a alga isolada.

A lavagem prévia em "tubos-filtro" e centrifugação do material coletado, antes do isolamento ao microscópio, facilitou muito o emprego do capilar. As lavagens nos "tubos-filtro", quando se desejou isolar espécies grandes como Ditylum brightwellii, Coscinodiscus concinnus etc., foi eficiente na eliminação de detritos, protozoários, fungos e a maioria das bactérias e al- 
gas menores. As centrifugações, além de promoverem uma maior concentração do material a ser isolado, também contribuiram para a eliminação de grande número de bactérias em suspensão.

As culturas iniciadas com células isoladas por capilares, após as lavagens citadas, apresentaram níveis de contaminação reduzidos, testadas após 10-15 dias de cultura, no caso de subculturas de Melosira moniliformis, Coscinodiscus concinnus, Nitzchia Zongissima e cinco dias, no caso de Skeletonema costatum.

0 processo de enriquecer com nutrientes (meio " $f$ " a 50\%) as subamostras do material coletado com garrafas "Van Dorn", mostrou ser eficiente para espécies relativamente pequenas, facilitando o seu isolamento.

Após o enriquecimento de amostras da região de Cananéia, houve um crescimento seletivo intenso de vārias espécies de nanofitoplâncton, com predominância de fitoflagelados tipo Platymonas, os quais foram separados posteriormente por fototropismo positivo. 0 simples emprego desta técnica, no entanto, nem sempre foi suficiente para a obtenção de culturas de fitoflagelados puras. Alguns protozoários e ocasionalmente outras algas, capturados junto com os fitoflagelados, apresentam também fototropismo positivo, sendo portanto necessário um posterior isolamento sob o microscópio.

Amostras enriquecidas da região de Ubatuba, tiveram um crescimento rápido e intenso de pequenas diatomáceas como Nitzschia closterium, Phaeodactylum tricornutum e outras não identificadas, além de uma espécie de cianofícea solitária (ou, sem formar colonias). Porēm, o organismo predominante foi uma espécie de Chaetoceros (Ch. simplex), geralmente solitário (sem formar cadeia). Com a inoculação de algumas gotas desta cultura mista em meio sólido para algas (MSA) e posterior separação das colônias resultantes, o isolamento de Phaeodactylum tricornutum, Chaetoceros simplex, Nitzschia closterium e Chlorella sp., não apresentou dificuldades.

A desvantagem deste método é que a escolha das espécies a serem isoladas está restrita às espécies que florescem, estimuladas pelo enriquecimento com nutrientes. Estas, geralmente, não são quantitativamente, representativas das populações naturais locais; tanto os fitoflagelados isolados como Chaetoceros simplex apareceram em números não predominantes relativamente a outras 
espécies, nas regiões de Cananéia e de Ubatuba, respectivamente (Kutner, 1972). Não podemos, entretanto, ter certeza absoluta destas conclusões, se levarmos em conta que os fixadores usados comumente para ofitoplâncton, como lugol ou formol, podem causar danos a vários tipos de organismos, principalmente aos fitoflagelados, e também os métodos de contagem apresentam baixa eficiência em muitas ocasiões .

\section{PURI FI CAÇÃO}

Para trabalhos experimentais fisiológicos e ecofisiológicos com culturas unialgais, o ideal é que as culturas estejam livres de bactériase as células algais em condições fisiológicas o mais próximo possível daquelas encontradas em condições naturais.

Os vários processos empregados na purificação de culturas atuam, uns mais, outros menos, como fatores deletérios à fisiologia e à morfologia das algas (Pringhsheim, 1946; Droop, 1967; Paredes, 1967-1968; Quraishi, 1968) .

Tendo em vista esse problema, discutir-se-āos resultados obtidos (culturas axênicas) e a metodologia empregada, considerando-se a utilização de tais culturas para experimentos ecofisiológicos.

\section{LAVAGENS}

Os métodos de lavagens por "tubos-filtro" e centrifugação, foram empregados com o objetivo de preparar as culturas unialgais para umposterior tratamento com antibióticos, isto é, eliminar a maior quantidade possível de bactérias em suspensão ou agregadas às células. Um dos fatores que influi no sucesso de utilização de antibióticos é a razão entre o número de células algais e bactérias favorável a um tratamento subseqüente de purificação (Quraishi, 1968).

Os resultados obtidos, entretanto, mostraram que lavagens cuidadosas podem ser utilizadas na obtenção direta de culturas unialgais axênicas rotineiramente, evitando-se os tratamentos químicos por motivos que serão discutidos adiante. 
A combinação das metodologias descritas por Chu (1947), Pringhsheim (1946) e Paredes (1967-1968), foi testada, repetidas vezes, com resultados positivos, nas seguintes seqüências de lavagens, comas células em fase exponencial de crescimento: "tubo-filtro" - incubação - reisolamento, para espécies grandes ou que formam cadeias ( $50 \mu \mathrm{m})$ e centrífuga - incubação-reisolamento para espécies pequenas $(<50 \mu \mathrm{m})$.

A vantagem de se trabalhar com culturas na fase exponencial de crescimento, deve-se ao fato de que nesta fase as células se apresentam em melhores condições fisiológicas, podendo também excretar algumas substâncias antibióticas (Steemann-Nielsen, 1955). Além disso, em culturas de diatomáceas em fases mais adiantadas do crescimento, é comum o aparecimento de bactérias entre as frústulas, e de difícil eliminação por métodos de lavagens (Paredes, 1967-1968).

Uma desvantagem deste método é sua grande dependência da habilidade do operador, e por isso, ter-se a necessidade de repetidas inoculações com células tratadas, para garantia dos resultados. Outra desvantagem, é a inutilidade desse método para espécies que apresentam bainhas gelatinosas, onde bactérias podem se desenvolver em grande nümero.

\section{ANTIBIÓTICOS}

0 emprego de antibióticos na purificação de culturas de algas, utilizado provavelmente pela primeira vez por Fish (1950), tem como vantagens a rapidez dos resultados, e a eliminação de bactérias firmemente agregadas às paredes celulares, entre as frústulas das diatomáceas e nas bainhas gelatinosas de certas algas.

Os resultados dos testes realizados (Tabs VI-VII) mostram que geralmente o tempo de 24 horas de exposição de algas ao antibiótico, a uma determinada concentração, pode ser substituido por 12 horas, sob concentrações mais altas. Verificou-se, também, um efeito sinergético entre os antibiōticos.

Das quatro espécies testadas, Skeletonema costatum e Chaetoceros wighami foram as que apresentaram menor viabilidade em concentrações mais elevadas, 
como as dos tubos IV e V (Tab. V). Apresentaram grande porcentagem de células "descoradas" mesmo em concentrações baixas, como no tubo III, e embora algumas subculturas dessem respostas negativas aos testes de presença de bactérias, as células algais não apresentaram viabilidade quando transferidas para meio sem antibióticos. PhaeodactyZum tricomutum apresentou grande resistência à mistura de antibióticos com alta porcentagem de viabilidade das células algais quando transferidas para meio sem antibióticos. Estes resultados concordam com aqueles obtidos por Spencer (1952) com Nitzschia closterium forma minutissima (= Phaeodactylum tricornutum).

Foram os fitoflagelados, porém, das quatro espécies testadas, que apresentaram maior resistência às concentrações elevadas da mistura de antibióticos (até à concentração VI), dando culturas axênicas com grande viabilidade das células algais em concentrações mais baixas como as dos tubos IV e III (Tabs V-VI).

Os resultados obtidos com antibióticos em cinco experimentos feitos em épocas diferentes, mostram que o sucesso na obtenção de culturas axênicas com células algais aparentemente normais fisiologicamente, nem sempre é constante, mesmo quando se considera os resultados obtidos com uma só espécie em uma só concentração.

Assim, nem sempre altas concentrações (com viabilidade para as algas) com 24 horas de exposição, deram respostas negativas aos testes de presença de bactérias nos três meios empregados para isso, e nem sempre baixas concentrações (tubo III) com 12 horas de exposição, deram células algais viāveis.

A fase "lag" do crescimento de células de PhaeodactyZum tricomutum tratadas com antibióticos com exposição de 24 horas, no tubo III, é muito longa comparada com células tratadas só com lavagens (Fig. 2) o que dá indícios de possíveis alterações fisiológicas (Spencer, 1952; Kumar, 1964). Outro indício de alterações fisiológicas é o fato de freqüentemente células de Phaeodactylum tricomutum mudarem de forma quando transferidas para meio sem antibióticos após exposição de 24 horas nos tubos III e IV. Células fusiformes de Phaeodactylum tricomutum mudaram para a forma oval após o tratamento e se mantiveram assim por 10-15 dias, aparecendo, gradualmente, após esse período, novamente células fusiformes. 
Devemos levar em conta, também, outras possíveis alterações induzidas por antibióticos, nem sempre facilmente detectáveis, como mutações genéticas (Droop, 1967; Kumar, 1964). Provasoli (1948, cit in: Lewin, 1962) observou que linhagens permanentemente "incolores"de Euglena gracilis var. bacillaris, foram produzidas depois que culturas "incolores" (crescidas no escuro) e culturas "verdes" (crescidas na luz) tinham sido expostas a concentrações de cerca de $1 \mathrm{mg} / \mathrm{ml}$ de estreptomicina na $1 \mathrm{uz}$ ou no escuro.

Estreptomicina provoca mutações citoplasmáticas em Chlamydomonas e em Euglena e há indícios que possa também ser mutagênica nuclear (Sager, 1974).

Richard et al., 1971 (cit in: Green, 1974) afirmam que o cicloeximide (actidione) inibe a síntese do DNA nuclear e as sínteses nos cloroplastos e mitocôndrias .

Galling \& Wolff, 1972 (cit in: Lorenzen \& Hesse, 1974) obtiveram reduções de DNA e RNA "em Chlorella sp. com concentrações de 0,5 mg/ml de neomicina. Também o cloranfenicol inibe a síntese mitocondrial e interfere no crescimento e na respiração de algas (Lloyd, 1974).

0 problema do crescimento intenso de fungos após o tratamento com antibióticos, foi suprimido com a utilização do actidione. No entanto, deve-se tomar cuidado com as concentrações deste antibiótico altamente algi'cida, principalmente para diatomāceas (Zehnder \& Hughes, 1958).

Baseando-se nos resultados obtidos, pode-se afirmar que o sucesso na utilização de antibióticos para purificação de culturas de algas e obtenção de células, fisiologicamente normais, depende de fatores como:

a) estado fisiológico das células a serem tratadas: células algais em fase de declínio de crescimento, p. ex., são intensamente atacadas por bactérias, além de apresentarem condições desfavoráveis para resistir aos antibióticos (Zobe11 \& Long, 1938; Quraishi, 1968; Paredes, 1967-1968).

b) sensibilidade das algas aos antibióticos: varia de espécie para espécie, de antibiótico para antibiótico, com a concentração e com o tempo de exposição. A estreptomicina, p. ex., pode causar clorose em muitas algas se forem expostas a altas concentrações por longos períodos (Provasoli et al., 1951, cit. in: Quraishi, 1968). 
De fato, o efeito da estreptomicina depende não só da sua concentração, como também da duração das exposições. Quando na determinação da concentração ótima deste antibiōtico na mistura de antibiōticos utilizada neste traba1ho, verificou-se que mesmo em concentrações relativamente baixas, mas em exposições de longa duração (5-10 dias), apareciam os efeitos de clorose em todas as espécies utilizadas. 0 mesmo efeito foi observado com o cloranfenicol. Estas observações estão de acordo comas afirmações de Quraishi (1968).

\section{RADIAÇOES ULTRA-VIOLETA}

Gerloff et al., (1950), apresentou o método como sendo de eficiência na purificação de cianofíceas. O autor conseguiu culturas axênicas da cianofícea Microcystis aemuginosa após tratamento com radiações U.V.

No entanto, a maioria dos autores é categórica em afirmar que o método é inconveniente na purificação de culturas de algas do fitoplâncton em geral, principalmente devido à resistência das bactérias, freqüentemente superior à das algas. Zobel1 \& Long (1938), não conseguiram determinar um comprimento de onda entre 2760 e $4100 \AA$ que fosse bactericida e não prejudicial às diatomáceas. Staub (1961, cit. in: Paredes, 1967-1968), usou as radiações U.V. em Oscillatoria mbenscens e Boalch (1961, cit.in: Paredes, 1967-1968), em culturas de Ectocarpus, sem sucesso, devido às algas apresentarem menor resistência do que as bactérias.

Nos testes realizados com quatro espécies, o objetivo foi determinar um tempo de exposição letal para bactérias, sem afetar as algas, pois é sabido que as radiações U.V. têm efeitos deletérios sobre as mesmas, ainda que em doses subletais, como p. ex., a degradação da clorofila (Steemann-Nielsen, 1964). Sager (1974) faz referências ao emprego de radiações U.V. na obtenção de mutantes em Chlarmydomonas.

Das quatro espécies testadas somente os fitoflagelados apresentaram resistência superior à das bactérias (Tab. VII). Porém, as células após otratamento originaram esporos de resistência(?), quando transferidas para meio "f $f_{1}$ novo. 
Skeletonema costatum, Chaetoceros wighami e Phaeodactylum tricormutum, entretanto, não mostraram viabilidade depois de expostas às radiações durante o tempo que seria necessário para eliminar as bactérias. Mesmo as células expostas por 2-4 minutos, apresentaram-se descoradas após 24 horas de manutenção em meio " $f_{1}$ " novo, terminando por morrer, o que concorda com as observações de Zobe11 \& Long (1938), Steemann-Nielsen (1964) e Paredes (19671968).

\section{MANUTENÇÃO DE ESTOQUES}

Espécies que formam cadeias (Skeletonema costatum e Melosina monilofor mis) não apresentaram bom crescimento em meio sōlido, sofrendo alterações na morfologia das células. As cadeias tornaram-se curvas, com menor número de células, com período de crescimento curto. Fitoflagelados freqüentemente perdem os flagelos e tornam-se arredondados. Isso jā tinha sido observado por Castellvi (1971) em Skeletonema costatum e por Quraishi (1968) em Tetraselmis tetrahele e Drmaliella primolecta. Mudanças na forma de Phaeodactylum tricomutum crescendo em meio sōlido também foram notadas, porém, não freqüentemente.

Células de Ditylum brightwellii com o envelhecimento da cultura vão perdendo suas "cerđás" e se deformando, enquanto aumenta muito o número de esporos de resistência.

De um modo geral, espécies grandes como Ditylum brightwellii, Coscinodiscus concinnus e Coscinodiscus jonesianus apresentaram um tempo de manutenção em estoque relativamente curto em todos os meios testados quando comparados com espécies pequenas como Phaeodactylzon tricornutum e Chlorella sp.

\section{CONCLUSÕES}

\section{ISOLAMENTO}

1 - 0 isolamento de espécies do fitoplâncton a partir de amostras de água deve ser feito o mais rapidamente possível, a fim de se evitar alteração na 
composição específica da amostra. Até 24 horas após as coletas, as amostras ainda se apresentavam em boas condições para o isolamento.

2 - Para o isolamento de uma determinada espécie de diatomácea de tamanho razoavelmente grande ou que forme cadeias, o uso de capilares de vidro foi o melhor método empregado. O isolamento de células em diferentes tubos de ensaio deve ser feito como medida de segurança, já que sempre ocorre morte de algumas delas.

3 - Para se isolar espécies relativamente pequenas e que não formam cadeias como Phaeodactylum tricornutum, Chaetoceros simplex, Chlorellasp., fitoflagelados etc., de uma cultura mista, a inoculação de algumas gotas dessa cultura em placas com meio sōlido é o método mais indicado. Como o meio sólido é também propício ao crescimento de bactérias marinhas, e suas colonias no meio são facilmente reconhecíveis, um controle preliminar do crescimento de bactérias pode jā ser feito no ato de isolamento.

4 - No caso específico de fitoflagelados, o uso do fototropismo positivo pode ser empregado como método auxiliar na separação, já que outros métodos têm que ser empregados posteriormente para a completa separação.

\section{PURI FI CAÇÃO}

1 - As culturas a serem purificadas devem estar sempre na fase exponencial de crescimento.

2 - A lavagem em tubos-filtro e também por centrifugação, é o método mais indicado para diminuir a razão bactérias: algas na cultura a ser tratada. Este método mostrou-se especialmente eficiente na obtenção de culturas axênicas de células grandes como Ditylum brightwelliii, Coscinodiscus jonesianus, Melosira moniliformis etc.

3 - Não foram obtidas culturas axênicas com a utilização de apenas um antibiótico em várias concentrações empregadas. Em mistura, os antibióticos apresentaram efeitos sinergéticos quanto à viabilidade das algas.

4 - As concentrações ótimas da mistura de antibióticos a serem utilizadas dependem do tempo de exposição: concentrações mais elevadas podem ser utilizadas em períodos mais curtos. 
5 - 0 emprego de antibióticos apesar de sua relativa comodidade e segurança na obtenção de culturas axênicas, não é aconselhāvel na purificação de culturas para fins de experimentos ecofisiológicos. Seus efeitos deletérios à fisiologia das células e possíveis mutações não detectáveis facilmente, são potencialmente maiores do que qualquer outro método mecânico empregado.

6 - A exposição de suspensões de células a radiações ultra-violeta, mostrou ser um método inteiramente desfavorável na purificação de culturas de diatomáceas. As algas geralmente apresentam menor resistência a esse tipo de radiações do que suas bactērias contaminantes.

7 - A combinação dos processos lavagem-incubação-reisolamento, é o método aconselhável na purificação de culturas para fins de estudos ecofisiológicos por apresentar menor dano à fisiologia das células; ser mais econômico e pela possibilidade de ser empregado, rotineiramente, em qualquer laboratório. As maiore's desvantagens do método são: não ser aplicável a espécies envolvidas por mucilagens, como cianofíceas, ou a espécies muito pequenas, e a eficiência dos resultados depender muito da habilidade do operador.

\section{MEIOS DE CULTURA}

1 - Os meios "f", " $f_{1}$ " e $\mathrm{ASP}_{2}$ apresentaram bons resultados no cultivo das espécies utilizadas neste trabalho. 0 meio "Erd-Schreiber" apresentou como inconveniente a inconstância dos rendimentos das espécies cultivadas. Se, no entanto, for utilizado ácido húmico puro em substituição ao extrato de solo, esse meio poderá ser utilizado com maior sucesso, uma vêz que a extração não é mais errática (Tundisi*, comunicação pessoal).

2 - 0 meio sólido não é aconselhável para cultivo de espécies que formam cadeias.

3 - Quando se deseja uma cultura em massa, os meios "f" e " $f_{1}$ " são os mais propícios. No entanto, esses meios são muito dispendiosos para o cultivo em grande escala e estudos sobre o custo real, - levando-se em conta o rendimento final ou a obtenção de um meio mais barato, - são necessários.

* Tundisi, J. G. - São Carlos, Universidade Federal de São Carlos, 1975. 


\section{SUMMARY}

The following methods were used to isolate some phytoplankton species: a) glass capilars - for big species (>50 $\mu \mathrm{m})$ or forming chains species like Ditylum brightwellii, Coscinodiscus jonesianus, Skeletonema costatum and Melosira moniliformis; b) spreading in Petri dishes with solid media for small species $(<50 \mu \mathrm{m})$ like Phaeodactylum tricomutum, Nitzschia closterium and Chaetoceros simplex. The positive phototropism of phytoflagellates was used to isolate them, with the spreading in agar Petri dishes. Washing methods were tested together with an antibiotic mixture and ultra-violet radiations for the purification of cultures. The use of antibiotics gave positive results and is a rapid method. However, it is not recommended to obtain axenic cultures for ecophysiological experiments. The combined washing method (washing growing - isolation) was efficient for the purification of big species or of those forming chains. This method is recommended for the obtention axenic cultures for ecophysiological experiments. The results of ultra-violet radiations experiments were not satisfactory.

\section{AGRADECI MENTO}

Agradeço à Direção do Instituto Oceanogräfico da Universidade de São Paulo, pelo apoio e pelas facilidades dispensadas na utilização de suas instalações, e à FAPESP, pelo apoio financeiro de parte deste trabalho.

\section{BIBLI OGRAFI A}

BALANTINE, D. 1953. Comparison of the different methods of estimating nannoplankton. J. mar. biol. Ass. U.K., 32(1):129-142.

CASTELLVI, J. 1971. Contribución a la biologia de S. costatum (Grev.) Cleve. Investigación pesq., 35(2):365-520.

CHU, S. P. 1947. Note on the technique of making bacteriafree cultures of marine diatoms. J. mar. biol. Ass. U.K., 26:296-302.

DROOP, M. R. 1967. A procedure for routine purification of algal cultures with antibiotics. Br. phyco1. Bull., 3(2):295-297. 
DROOP, M. R. 1969. Algae. In: Norris, T. R. \& Ribbons, D. W., ed.Methods in microbiology. London, Academic Press, p. 270-308.

FISH, G. R. 1950. A method of obtaining bacteria-free cultures of a marine flagellate and Enteromorpha intestinalis using penicillin. Acta Horti gothoburg, 18:82-89.

GERLOFF, G. C.; FITZGERALD, P. \& SKOOG, F. 1950. The isolation, purification, and culture of blue-green algae. Am. J. Bot., 37:216-218.

GREEN, B. R. 1974. Nucleic acids and their metabolism. In: Stewart, W.D.P., ed.- Algal physiology and biochemistry. Oxford, Blackwe1l, p. 281-313.

GROSS, F. 1937. Notes on the culture of some marine organisms. J. mar. biol. Ass. U.K., 21(2):753-768.

GUILLARD, R. R. L. 1973. Methods for microflagellates and nannoplankton. In: Stein, J. R., ed.- Handbook of phycological methods. Culture Methods and Growth Measurements. Cambridge, University Press, 69-85.

— RYTHER, J. H. 1962. Studies of marine plankton diatoms. I. Cyclotella hustedt and Detonula confervacea (Cleve) Gran. Can. J. Microbio1., 8:229-239.

HARVEY, H. W. 1955. The chemistry and fertility of sea waters. London, Cambridge University Press, viii $+224 p$.

KAIN, J. M. \& FOGG, G. E. 1960. Studies on the growth of marine phytoplankton. III. Prorocentmom micans Ehrengerg. J. mar. biol. Ass. U.K., $39: 33-50$.

KUMAR, H. D. 1964. Streptomycin and penicillin induced inhibition of growth and pigment production in blue-green algae and production of strains of Anacystis nidulans resistant to these antibiotics. J. exp. Bot., $15: 232-250$.

KUTNER, M. B. B. 1972. Variação estacional e distribuição do fitoplâncton na região de Cananéia. Tese de doutoramento. São Paulo, Instituto de Biociências da Universidade de São Paulo, 104 p.

LEWIN, R. A., ed. 1962. Physiology and biochemistry of algae. New York, Academic Press, 929 p.

LLOYD, D. 1974. Dark respiration. In: Stewart, W. D. P., ed.- A1gal physiology and biochemistry. Oxford, Blackwe11, p. 505-529.

LORENZEN, H. \& HESSE, M. 1974. Synchronous cultures. In: Stewart, W. D. P., ed.- Algal physiology and biochemistry. Oxford, Blackwe11, p. 894-908.

MINGOIA, Q. 1967. Química farmacêutica. São Paulo, Melhoramentos/ EDUSP, $787 \mathrm{p}$. 
PAREDES, J. F. 1967-1968. Some methods used to obtain bacteria-free cultures of marine phytoplankton. Mems Inst. Invest. cient. Moçamb., 9, (A), (Ciências Biológicas), p. 127-141.

PRAKASH, A.; RASHID, M.A.; JENSEN, A. \& SUBRA RAO, D.V. 1973. Influence of humic substances on the growth of marine phytoplankton: diatoms. Limno1. Oceanogr., 18(4.):516-524.

PRINGSHEIM, E. G. 1946. Pure cultures of algae. Cambridge, Univ . Press, London, $119 \mathrm{p}$.

PROVASOLI, L.; McLAUGHLIN, J. J. A. \& DROOP, M. R. 1957. The development of artificial media for marine algae. Arch. Mikrobiol., 25:392-425.

QURAISHI, F. 0. 1968. The reactions of phytoplankton to different illumination regimes. Ph. D. thesis. Univ. Wales (Bangor).

SAGER, R. 1974. Nuclear and cytoplasmatic inheritance in green algae. In: Stewart, W. D. P., ed.- Algal physiology and biochemistry. Oxford, Blackwe11, p. 314-345.

SPENCER, C. P. 1952. On the use of antibiotic for isolating bacteriafree cultures of marine phytoplankton organisms. J. mar. biol. Ass. U.K., $31: 87-106$.

STEEMANN-NIELSEN, E. 1955. The production of antibiotics by plankton algae and its effects upon bacterial activities in the sea. Pap. in Mar. Bio1. and Oceanogr. Deep Sea Res., 3 Supp1., 281 p.

1964. On a complication in marine productivity work due to the influence of ultraviolet light. J. Cons. perm. int. Explor. Mer, 29(2):130-135.

UMEBAYASHI, 0. 1972. Preservation of some culture diatoms. Bull. Tokai reg. Fish Res. Lab., (69):55-62.

ZEHNDER, A. \& HUGHES, E. 0. 1958. The antialgal activity of actidione. Can. J. Microbio1., 4:399-408.

ZOBELL, C. E. \& LONG, J. H. 1938. Studies on the isolation of bacteria-free culture marine phytoplankton. J. mar. Res., 1:328-333.

(Received July 21/1976) 